\title{
HUBUNGAN KOMUNIKASI PEMASARAN DENGAN TINGKAT KUALITAS DAYA SAING UMKM KERAJINAN DI KOTA BOGOR
}

\section{(Relationship Marketing Communication with Quality Level Competitiveness of SMES Craft in Bogor)}

\author{
Tiffany Diahnisa ${ }^{1)}$ dan Yatri Indah Kusumastuti ${ }^{1)}$ \\ ${ }^{1)}$ Departemen Sains Komunikasi dan Pengembangan Masyarakat, Fakultas Ekologi Manusia, Institut \\ Pertanian Bogor, Darmaga Bogor 16680, Indonesia \\ Email : diahnisatiffany28@gmail.com; yatri.kusumastuti@apps.ipb.ac.id
}

\begin{abstract}
Micro, Small, and Medium Enterprises (MSME) has an important role in local and national economy. Many MSME's product penetrated local, national, and international market. This study aims to identify the implementation of marketing communication used by MSMEs craft, identify quality level of competitiveness of MSME's craft, analyze the relationship characteristics of MSME's craft with the implementation of marketing communications, and analyze the relationship between the implementation of marketing communications with the quality level of competitiveness of MSME's craft. This study combined quantitative approach using questioner method and supported by qualitative data using depth interview method. The results showed that the implementation of the marketing communications MSME's craft in the city of Bogor has classified moderate, while mostly using social media as a communication medium and Word of Mouth (WOM) as the promotion mix, while in terms of the quality competitiveness, MSME's craft in Bogor has classified moderate in quality level of competitiveness. The conclusion from this study is the implementation of marketing communications especially variety of media communication and promotion mix related quality level of competitiveness.
\end{abstract}

Keywords: communication media, economy, promotion mix

\begin{abstract}
ABSTRAK
Usaha Mikro, Kecil, dan Menengah (UMKM) memiliki peran penting dalam perekonomian lokal dan nasional. Banyak produk UMKM menembus pasar lokal, nasional, dan internasional. Penelitian ini bertujuan untuk mengidentifikasi pelaksanaan komunikasi pemasaran yang digunakan oleh kerajinan UMKM, mengidentifikasi tingkat kualitas daya saing kerajinan UMKM, menganalisis karakteristik hubungan kerajinan UMKM dengan pelaksanaan komunikasi pemasaran, dan menganalisis hubungan antara pelaksanaan komunikasi pemasaran dengan tingkat kualitas daya saing kerajinan UMKM. Penelitian ini mengkombinasikan pendekatan kuantitatif dengan menggunakan metode kuesioner dan didukung oleh data kualitatif dengan menggunakan metode wawancara mendalam. Hasil penelitian menunjukkan bahwa pelaksanaan kerajinan komunikasi pemasaran UMKM di Kota Bogor telah diklasifikasikan sedang, sementara sebagian besar menggunakan media sosial sebagai media komunikasi dan WOM (mulut ke mulut) sebagai bauran promosi, sedangkan dalam hal daya saing kualitas, kerajinan UMKM di Bogor telah diklasifikasikan sedang dalam tingkat kualitas daya saing. Kesimpulan dari penelitian ini adalah implementasi dari komunikasi pemasaran terutama berbagai media komunikasi dan bauran promosi terkait tingkat kualitas daya saing.
\end{abstract}

Kata kunci: bauran promosi, media komunikasi, perekonomian 


\section{PENDAHULUAN}

Komunikasi pemasaran adalah upaya komunikasi yang dilakukan untuk memperkenalkan produk suatu perusahaan baik barang atau jasa kepada masyarakat, sehingga masyarakat tahu dan kemudian tertarik untuk menggunakan produk tersebut. Seorang komunikator dalam komunikasi pemasaran harus mampu menjelaskan dan menyampaikan informasi mengenai suatu produk yang ditawarkan dengan bahasa yang komunikatif dan mudah dipahami. Selain itu komunikasi pemasaran sebagai usaha untuk menyampaikan pesan kepada publik, terutama konsumen sasaran mengenai keberadaan suatu produk di pasar (Kotler 2000) seperti yang dikutip oleh (Kusumastuti 2009).

Pelaku usaha melakukan berbagai upaya dalam rangka menjalankan komunikasi pemasaran yang efektif. Salah satunya dengan mengaplikasikan bauran promosi (promotion mix), yaitu periklanan (advertising), promosi penjualan (sales promotion), hubungan masyarakat dan publisitas (public relation and publicity), penjualan tatap muka (personal selling), dan penjualan langsung (direct selling).

Sebagaimana yang dilakukan oleh Usaha Mikro, Kecil, dan Menengah (UMKM). UMKM memiliki peran penting dalam perekonomian suatu negara baik di negara maju maupun di negara berkembang. Berdasarkan data dari Biro Pusat Statistik (BPS) yang dikutip oleh Widhi (2005), jumlah tenaga kerja yang terserap dalam sektor UMKM sekitar 80 persen sampai 90 persen dari total tenaga kerja di Indonesia. Hal ini didukung oleh Urata (2000) seperti yang dikutip oleh Sulistyastuti dan Dyah (2004) yang mengemukakan tentang beberapa peran UMKM, antara lain sebagai pemain utama dalam kegiatan ekonomi di Indonesia, penyedia kesempatan kerja, pemain penting dalam pembangunan ekonomi lokal dan pengembangan masyarakat, pencipta pasar dan inovasi melalui fleksibilitas dan sensivitas serta keterkaitan dinamis antar kegiatan perusahaan, dan memberikan kontribusi terhadap peningkatan ekspor non migas.

Menghadapi era pasar bebas di tahun 2015, persaingan tidak hanya terjadi antar produk dalam negeri, tetapi juga bersaing dengan produk-produk luar negeri. Upaya yang dapat dilakukan ialah meningkatkan kualitas daya saing melalui pengembangan sektor usaha. Sebagaimana yang dilakukan oleh pemerintah Kota Bogor untuk mengembangkan usaha kerajinan di Kota Bogor, dimana usaha tersebut didukung oleh lembaga yang menaungi, memfasilitasi, dan membantu para pelaku usaha khususnya UMKM kerajinan untuk terus berkembang, bertahan, dan berdaya saing. Beberapa lembaga tersebut yaitu Dewan Kerajinan Nasional (Dekranasda), Dinas Koperasi dan UMKM Kota Bogor, Dinas Kebudayaan dan Pariwisata, serta Dinas Perdagangan dan Industri.

Berbagai pelatihan, pameran, galeri produk, dan komunikasi pemasaran disediakan guna memfasilitasi perajin. Hal tersebut yang dimanfaatkan oleh para pelaku UMKM di Kota Bogor, Jawa Barat, khususnya UMKM dalam bidang kerajinan untuk meningkatkan kualitas daya saing. Berbagai jenis produk kerajinan dihasilkan kemudian dipasarkan baik di Bogor, beberapa kota sekitar Bogor, nasional, regional hingga menembus pasar internasional. Akan tetapi kuatnya persaingan di dunia usaha membuat para pelaku usaha, harus mampu beradaptasi dan bersaing secara sehat dengan produk impor. Produk yang dihasilkan baik barang maupun jasa harus dapat menarik minat konsumen potensial dan mempertahankan konsumen tetap.

Menurut Kepala Kantor Koperasi dan UMKM Kota Bogor, para perajin di Kota Bogor kurang memiliki kreatifitas dalam mengembangkan produknya, belum mampu memenuhi permintaan pasar, produk yang dihasilkan belum dapat menunjukkan ciri khas Kota Bogor dan belum banyak dikenal oleh masyarakat luas. Berbagai upaya dapat dilakukan agar produk dapat diketahui oleh masyarakat, salah satunya melalui strategi komunikasi pemasaran untuk meningkatkan kualitas daya saing. Oleh karena itu, berdasarkan uraian di atas, maka hubungan pelaksanaan komunikasi pemasaran dengan tingkat kualitas daya saing UMKM kerajinan di Kota Bogor relevan untuk diteliti.

Berdasarkan uraian di atas maka rumusan masalah yang akan diteliti, antara lain: 1. bagaimana pelaksanaan komunikasi pemasaran yang digunakan oleh UMKM kerajinan di Kota Bogor?; 2. bagaimana tingkat kualitas daya saing UMKM kerajinan di Kota Bogor?; 3. bagaimana hubungan karakteristik UMKM kerajinan dengan pelaksanaan komunikasi pemasaran?; dan 4. bagaimana hubungan pelaksanaan komunikasi pemasaran 
dengan tingkat kualitas daya saing UMKM kerajinan di Kota Bogor?

Adapun tujuan dari penelitian ini yaitu mengidentifikasi pelaksanaan komunikasi pemasaran yang digunakan oleh UMKM kerajinan di Kota Bogor; mengidentifikasi tingkat kualitas daya saing UMKM kerajinan di Kota Bogor; Menganalisis hubungan karakteristik UMKM kerajinan dengan pelaksanaan komunikasi pemasaran; dan menganalisis hubungan pelaksanaan komunikasi pemasaran dengan tingkat kualitas daya saing UMKM kerajinan di Kota Bogor.

\section{PENDEKATAN TEORITIS}

\section{Komunikasi Pemasaran}

Komunikasi pemasaran sebagai usaha untuk menyampaikan pesan kepada publik, terutama konsumen sasaran, mengenai keberadaan suatu produk di pasar (Kotler 2000) seperti yang dikutip oleh (Kusumastuti 2009). Perusahaan melakukan berbagai upaya dalam rangka menjalankan komunikasi pemasaran yang efektif, salah satunya dengan mengaplikasikan bauran promosi. Bauran promosi menurut Tjiptono (2008) ialah tugas-tugas dimana perusahaan sebagai produsen mengenalkan, menyebarkan informasi, mempengaruhi konsumen melalui sebuah instrumen pemasaran (periklanan, promosi penjualan, publisitas, penjualan tatap muka, dan pemasaran langsung), sehingga konsumen sebagai kelompok sasaran dapat mengetahui, tertarik, dan selanjutnya membeli atau mengkonsumsi produk tersebut. Bentuk komunikasi pemasaran lainnya yang masih efektif digunakan ialah Word of Mouth (WOM) atau berita dari mulut ke mulut.Menurut Kotler dan Keller (2009), berita dari mulut ke mulut bisa sangat efektif untuk bisnis kecil yang di dalamnya pelanggan dapat merasakan hubungan yang lebih pribadi. Terdapat dua bentuk khusus berita dari mulut ke mulut, yaitu pemasaran Buzz dan Viral.

\section{Media Komunikasi Pemasaran}

Kegiatan komunikasi pemasaran salah satunya adalah perlu dukungan dari media. Melalui pemilihan saluran komunikasi yang tepat, pesan dari penjual kepada pembeli dapat berlangsung efektif. Kusumastuti (2009) mengemukakan pendapat bahwa komunikasi pemasaran membagi media atas tiga kelompok, antara lain: media massa, terdiri atas media elektronik dan media cetak; media kelompok, biasa digunakan pada kegiatan-kegiatan yang melibatkan kelompok tertentu, misalnya video presentasi; dan media personal, seperti katalog, profil korporat, dan folder. Mugniesyah (2009) menyebutkan bahwa seiring dengan berkembangnya teknologi komunikasi dan informasi, mulai muncul media yang berbasis teknologi komputer dan menggabungkan semua fungsi media, sehingga media ini mampu menjangkau khalayak di banyak lokasi. Media tersebut dikenal dengan sebutan media hibrida yaitu internet dan media sosial.

\section{Usaha Mikro, Kecil, dan Menengah (UMKM)}

UMKM merupakan usaha yang mampu bertahan ketika krisis ekonomi terjadi di Indonesia. Usaha ini mampu menyerap tenaga kerja dan berkontribusi dalam mendistribusikan hasil-hasil pembangunan dan menggunakan sumber daya lokal. Terdapat ciri khas dari UMKM, yaitu modal yang kecil, jumlah pekerja yang sedikit, risiko yang sedikit tinggi tetapi return tinggi, biasanya digerakkan dari rumah tangga, dan membawa kewirausahaan bagi pemiliknya (Isnaini 2010). Menurut UndangUndang Nomor 20 Tahun 2008 Tentang Usaha Mikro, kecil, dan Menengah, skala UMKM dibagi menjadi tiga berdasarkan aset dan nilai penjualan, yaitu mikro (aset $\leq 50$ Juta dan nilai penjualan $\leq$ 300 Juta), kecil (aset 50 Juta $<\mathrm{x} \leq 500$ Juta dan nilai penjualan 300 Juta $<y \leq 2.5 \mathrm{M}$ ), dan menengah (aset 500 Juta $<\mathrm{x} \leq 10 \mathrm{M}$ dan nilai penjualan $2,5 \mathrm{M}<\mathrm{y} \leq 50 \mathrm{M}$ ). Mengacu pada data BPS yang dikutip oleh Tambunan (2009) diketahui bahwa sebagian besar pengusaha UMKM mengungkapkan alasan kegiatan usaha yang mereka lakukan adalah latar belakang ekonomi. Hal ini didukung dengan kondisi tingkat pendidikan pengusaha yang mayoritas tergolong rendah. Akan tetapi, beberapa pengusaha menjalankan bisnis keluarga secara turun-temurun.

\section{Daya Saing UMKM}

UMKM dalam usaha untuk mempertahankan keberadaannya harus dapat melihat peluang usaha dengan baik, khususnya saingan dari luar negeri melalui barang impor. Hal ini memunculkan suatu daya saing. Daya saing UMKM ialah kemampuan untuk memperoleh posisi dan mempertahankan diri dalam kompetisi dan pangsa pasar. Kunci suatu perusahaan untuk dapat berdaya saing ialah inovasi. Pengukuran daya saing UMKM dibagi menjadi daya saing produk dan daya saing perusahaan. Daya 
saing produk melihat bagaimana perusahaan tersebut dalam menghasilkan produk, sedangkan daya saing perusahaan merupakan cerminan dari daya saing produk, dimana tingkat daya saing sebuah perusahaan mendorong atau menentukan daya saing produk yang dibuatnya (Tambunan 2009). Indikator-indikator yang dapat digunakan dalam pengukuran daya saing, yaitu pertumbuhan nilai atau volume output, pangsa PDB, pangsa pasar, nilai omset, profit, tingkat pendidikan ratarata pekerja dan pengusaha, pengeluaran $R \& D$, jumlah sertifikat standardisasi yang dimiliki dan jumlah paten yang dibeli, standardisasi, jenis teknologi yang digunakan, produktivitas atau efisiensi, nilai mesin dan peralatan produksi atau nilai aset, jumlah pengeluaran promosi, dan jaringan kerja atau kerja sama dengan pihak lain.

\section{KERANGKA PEMIKIRAN}

UMKM memiliki karakteristik usaha yang dapat dilihat dari skala usaha dan tingkat pendidikan pelaku usaha. Karakteristik UMKM menjadi salah satu faktor bagaimana pelaksanaan komunikasi pemasaran yang dilakukan untuk mengenalkan dan memasarkan produk. Melalui komunikasi pemasaran, suatu usaha dapat meningkatkan kualitas daya saing.

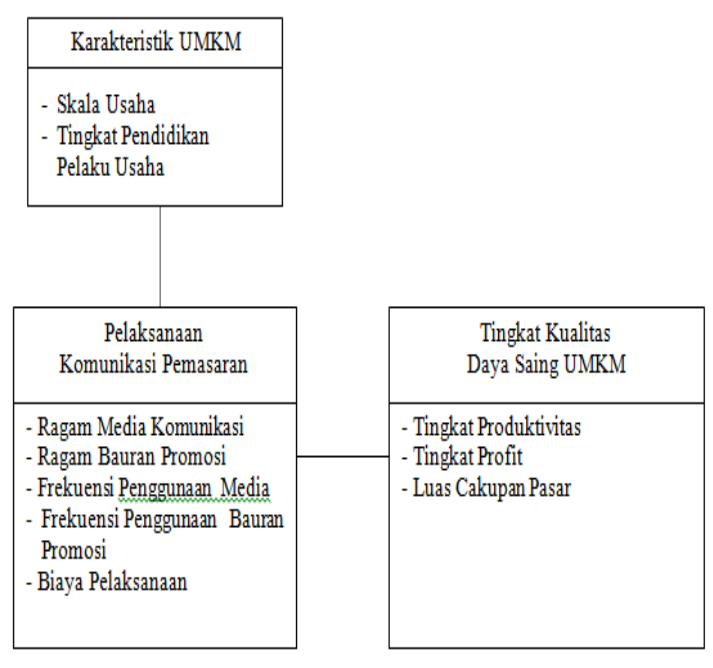

Keterangan:

— : Berhubungan

Gambar 1 Kerangka pemikiran

\section{Hipotesis}

1. Diduga terdapat hubungan antara karateristik UMKM dengan pelaksanaan komunikasi pemasaran.
2. Diduga terdapat hubungan antara pelaksanaan komunikasi pemasaran dengan tingkat kualitas daya saing.

\section{METODE PENELITIAN}

Penelitian ini dilakukan pada UMKM kerajinan di Kota Bogor dengan pertimbangan, antara lain: UMKM merupakan usaha yang terus berkembang saat ini dengan melaksanakan komunikasi pemasaran, terdapat UMKM kerajinan di Kota Bogor yang melaksanakan komunikasi pemasaran, dan terdapat lembaga yang menaungi UMKM kerajinan di Kota Bogor baik dalam hal pelatihan maupun pelaksanaan pemasaran. Penelitian ini dilaksanakan dari bulan September 2014 sampai dengan Januari 2015.

Populasi penelitian ini ialah seluruh UMKM kerajinan di bawah naungan Dekranasda Kota Bogor sebanyak 64 UMKM. Akan tetapi setelah di lapangan penelitian, hanya 30 UMKM kerajinan di Kota Bogor yang masih aktif menjalankan usaha, aktif melaksanakan komunikasi pemasaran, dan bersedia diwawancara. Unit analisis dalam penelitian ini ialah rumah tangga. Informan dalam penelitian ini adalah lima lembaga yang terkait dengan UMKM di Bogor, yaitu Pemerintah Kota Bogor, Kadin (Kamar Dagang dan Industri) Kota Bogor, Dekranasda (Dewan Kerajinan Nasional), Dinas Kebudayaan dan Pariwisata Kota Bogor, dan Dinas Koperasi dan UMKM Kota Bogor.

Data yang sudah terkumpul dianalisis secara kuantitatif menggunakan microsoft excel 2010 dan SPSS for Windows versi 16. Uji statistik yang digunakan yaitu uji korelasi Rank Spearman untuk melihat pengaruh antara variabel yang akan diuji. Data kualitatif dari wawancara mendalam dan observasi disajikan secara deskriptif untuk mendukung dan memperkuat analisis kuantitatif. Selain itu hasil pengolahan data disajikan dalam bentuk tabulasi frekuensi dan diagram lingkaran, dan teks naratif. Tahap terakhir yaitu menarik kesimpulan sesuai dengan rumusan masalah dan tujuan penelitian.

\section{UMKM KERAJINAN DI KOTA BOGOR}

Sektor usaha khususnya kerajinan di Kota Bogor tergolong usaha yang berkembang, dimana sektor ini memberi kontribusi bagi peningkatan perekonomian Kota Bogor. Berdasarkan data Bagian Ekonomi Pemerintah Kota Bogor pada 
tahun 2014, pada tahun 2012 PDRB Kota Bogor sebesar $\mathrm{Rp}$ 22,712,531.28 atau sekitar 18.96 persen, kemudian mengalami peningkatan sebesar 3.61 persen pada tahun 2013 dengan PDRB sebesar Rp 27,035,861.34 atau 22.57 persen. Usaha Mikro, Kecil, dan Menengah (UMKM) kerajinan di Kota Bogor sudah mulai berkembang sejak tahun 2000 bahkan pada tahun 1995 jumlah UMKM mulai bertambah.

Melihat potensi yang besar pada usaha kerajinan, Pemerintah Kota Bogor berupaya untuk mengembangkan sektor ini, salah satunya melalui galeri UMKM kerajinan yaitu Dekranasda yang membantu pemerintah dalam melindungi, menggali, melestarikan, membina serta mengembangkan seni kriya kerajinan.

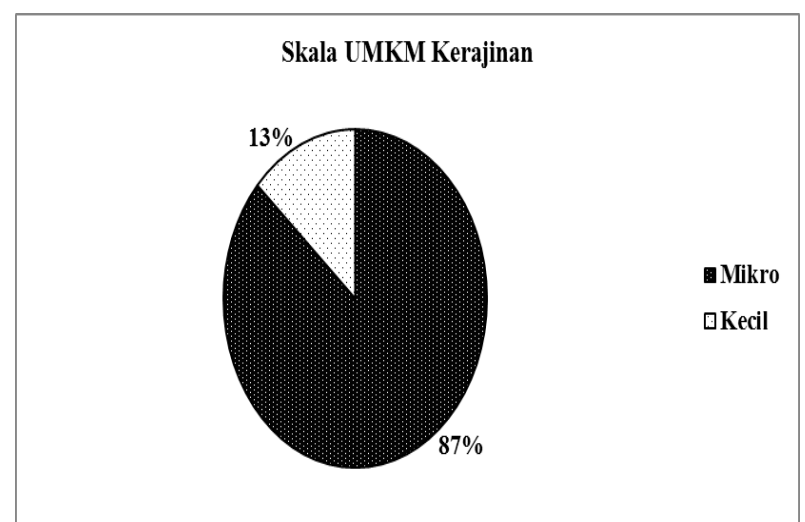

\footnotetext{
Gambar 2 Persentase skala UMKM kerajinan di Kota Bogor pada tahun 2014
}

Sebagian besar UMKM kerajinan di Kota Bogor yaitu sebanyak 87 persen tergolong usaha kecil dengan tingkat pendidikan pelaku usaha tergolong sedang (lulus SMP/SMA). Adapun latar belakang usaha kerajinan di Kota Bogor didominasi oleh hobi yaitu sebesar 63 persen. Alasan lainnya ialah karena usaha warisan, prospek dan peluang usaha, pemberdayaan, dan melestarikan budaya. Berbagai produk kerajinan dihasilkan seperti gelang, kalung, bros, tas dari bahan daur ulang, alat musik dari bambu, dan lain-lain. Produk kerajinan tersebut diperkenalkan dan dipasarkan baik oleh UMKM sendiri maupun pihak lain antara lain Dekranasda, pemerintah Kota Bogor, dan swasta. Akan tetapi pelaku usaha kerajinan di Kota Bogor mengalami hambatan dalam mengembangkan usahanya, dimana keterampilan pekerja menjadi hambatan yang paling besar. Hal ini berpengaruh terhadap kualitas dan kuantitas produk. Padahal untuk menghasilkan barang kerajinan diperlukan keterampilan, inovasi, dan kreativitas. Sehingga para pemilik memberi pelatihan keterampilan sebelum menerima pekerja.

\section{PELAKSANAAN KOMUNIKASI PEMASARAN UMKM KERAJINAN DI KOTA BOGOR}

Berdasarkan hasil penelitian, pelaksanaan komunikasi pemasaran yang dilakukan oleh UMKM kerajinan di Kota Bogor tergolong sedang yaitu sebesar 69 persen. Hal ini menunjukkan bahwa pelaku usaha kerajinan belum melakukan upaya komunikasi pemasaran secara optimal. Sebagian besar UMKM kerajinan yaitu 53 persen menggunakan media hibrida dalam memasarkan produk, seperti Facebook dan website.

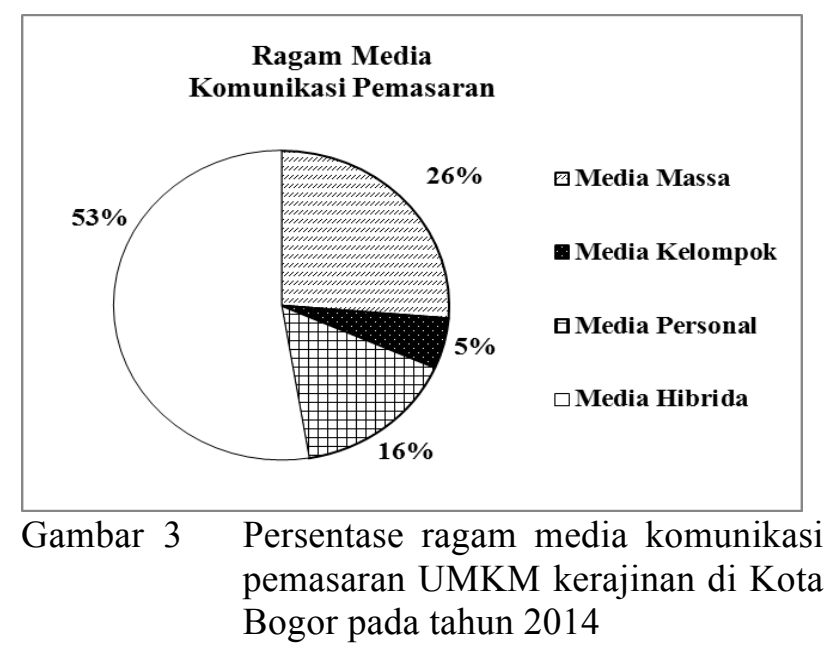

Media hibrida dipilih karena sifat media ini yang dapat menjangkau khalayak luas. Selain itu mudah diakses dengan menggunakan smartphone dan mengurangi biaya dibandingkan harus cetak brosur atau leaflet. Akan tetapi penggunaan ragam media komunikasi masih tergolong sedang yaitu sebesar 53 persen, dimana frekuensi penggunaan media hanya 10-16 kali dalam setahun.

Upaya pemasaran juga dilakukan menggunakan bauran promosi, dimana sebesar 27 persen UMKM menggunakan WOM (mulut ke mulut). Melalui WOM, seorang konsumen yang pernah membeli produk kerajinan memberi informasi pada calon konsumen mengenai produk tersebut, sehingga calon konsumen mengetahui informasi produk dan apabila tertarik, maka kemungkinan besar membeli produk tersebut. Selain itu UMKM juga aktif melakukan promosi penjualan melalui pameran gratis yang diadakan oleh pemerintah maupun swasta di tingkat nasional hingga internasional 
seperti Inacraft, pameran HUT Kota Bogor, dan lain sebagainya.

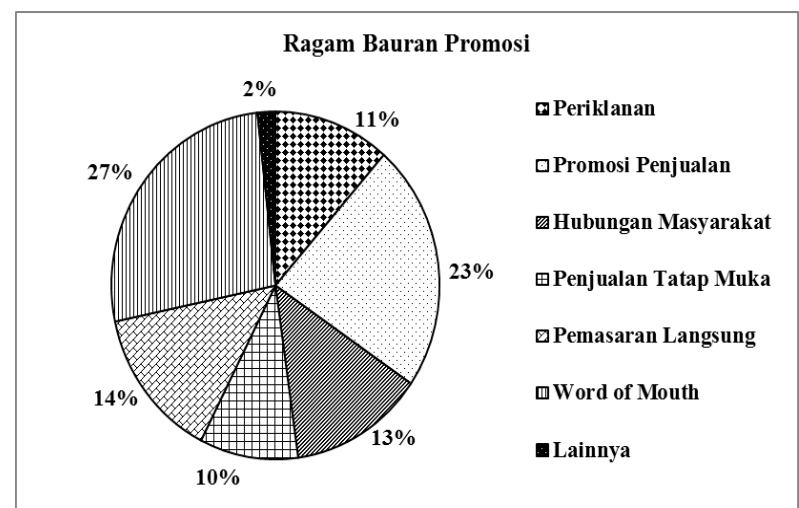

Gambar 4 Persentase ragam bauran promosi yang digunakan oleh UMK kerajinan di Kota Bogor pada tahun 2014

Penggunaan media komunikasi dan bauran promosi dalam melaksanakan komunikasi pemasaran tidak dapat dipisahkan dari anggaran biaya. Biaya pelaksanaan komunikasi pemasaran UMKM kerajinan di Kota Bogor sebagian besar tergolong rendah, yaitu sebesar 43.33 persen atau 13 UMKM, dimana UMKM tersebut memiliki skala usaha mikro. Hal ini menunjukkan bahwa UMKM kerajinan tidak memiliki anggaran khusus untuk pemasaran, selain itu hanya sebagian kecil UMKM kerajinan yang mengeluarkan biaya tinggi untuk melakukan kegiatan promosi.

\section{TINGKAT KUALITAS DAYA SAING UMKM KERAJINAN DI KOTA BOGOR}

Hasil penelitian menunjukkan bahwa tingkat kualitas daya saing pada UMKM kerajinan di Kota Bogor termasuk sedang dengan persentase sebesar 47 persen, Sebagian besar UMKM kerajinan di Kota Bogor sudah termasuk berkembang, akan tetapi masih terkendala dalam hal keterampilan pekerja, modal, akses pasar dan informasi, teknologi, dan lain sebagainya. Hal lain ialah sebagian besar UMKM tidak memiliki pembukuan yang jelas mengenai omset, biaya produksi, dan keuntungan per bulan maupun per tahun.

Tingkat kualitas daya saing dapat diukur dari tingkat produktivitas, tingkat profit, dan luas cakupan pasar. Pertama, tingkat produktivitas diukur dari nilai omset yang dihasilkan UMKM kerajinan di Kota Bogor, dimana memiliki tingkat produktivitas tergolong sedang yaitu sebesar 46.67 persen atau 14 UMKM, dimana sebanyak 13
UMKM berskala mikro. Rata-rata omset yang didapat oleh UMKM kerajinan di Kota Bogor sebesar $\mathrm{Rp} 194.000 .000,00$ per tahun dengan kisaran antara $\mathrm{Rp} 24.000 .000,00-\mathrm{Rp} 364.000 .000,00$ per tahun. Sebagian perajin menyediakan ready stock termasuk untuk dijadikan sample. Ada UMKM yang tidak menyediakan ready stock, karena menyediakan sesuai permintaan Akan tetapi ada yang menyediakan ready stock dan sistem custom (pemesanan sesuai keinginan).

Kedua, dalam hal tingkat profit, sebagian besar UMKM kerajinan tergolong sedang, yaitu sebesar 63.33 persen atau 19 UMKM, dimana sebanyak 18 UMKM termasuk usaha berskala mikro. Rata-rata keuntungan yang didapat oleh UMKM kerajinan di Kota Bogor sebesar Rp 93.000.000,00 per tahun dengan kisaran $\mathrm{Rp} 6.000 .000,00$ per tahun untuk yang terendah dan tertinggi Rp 181.000.000,00 per tahun.

Ketiga, UMKM kerajinan di Kota Bogor memiliki luas cakupan pasar yang tergolong sedang, yaitu sebesar 76.67 persen atau 23 UMKM, dimana sebanyak 19. Sebagian besar UMKM kerajinan di Kota Bogor sudah memiliki segmentasi pasar nasional, bahkan beberapa produk sudah dipamerkan di tingkat internasional, seperti produk wayang golek tersebut sudah diimpor ke Negara Belanda, walaupun melalui impor tidak langsung.

\section{HUBUNGAN KARAKTERISTIK UMKM KERAJINAN DENGAN PELAKSANAAN KOMUNIKASI PEMASARAN}

Hasil uji korelasi antara variabel-variabel karakteristik UMKM (skala usaha dan tingkat pendidikan pelaku usaha) dengan variabel-variabel pelaksanaan komunikasi pemasaran (ragam media komunikasi, ragam bauran promosi, frekuensi penggunaan media komunikasi, frekuensi penggunaan bauran promosi, dan biaya pelaksanaan komunikasi pemasaran) menunjukkan nilai koefisien korelasi pada masing-masing variabel yang diuji yang lebih besar dari taraf nyata atau $\alpha$ sebesar 0.05. Sehingga, dapat disimpulkan bahwa antara variabel karakteristik UMKM kerajinan dengan variabel pelaksanaan komunikasi pemasaran tidak terdapat hubungan yang nyata dan tidak signifikan. 


\section{HUBUNGAN PELAKSANAAN KOMUNIKASI PEMASARAN DENGAN TINGKAT KUALITAS DAYA SAING UMKM}

Hasil uji korelasi Rank Spearman antara pelaksanaan komunikasi pemasaran dengan kualitas daya saing menunjukkan bahwa nilai koefisien korelasi sebesar 0.443 . Nilai tersebut menyatakan bahwa terdapat korelasi yang moderat. Nilai hitung tersebut berada diantara nilai $0.25-0.5$. Sarwono (2009) menjelaskan bahwa jika hasil uji berada di antara nilai tersebut maka terdapat korelasi atau hubungan yang cukup kuat, sedangkan untuk nilai signifikasi ialah sebesar 0.014 , dimana nilai tersebut lebih kecil dari taraf nyata atau $\alpha$ sebesar 0.05 . Hal ini menunjukkan bahwa kedua variabel tersebut berhubungan signifikan. Sehingga, dapat disimpulkan bahwa antara variabel pelaksanaan komunikasi pemasaran dengan kualitas daya saing UMKM terdapat hubungan yang moderat dan signifikan.

\section{SIMPULAN DAN SARAN}

\section{Simpulan}

Pemasaran yang dilakukan oleh perajin di Kota Bogor umumnya masih dilakukan oleh pihak UMKM sendiri. UMKM kerajinan di Kota Bogor dominan menggunakan media hibrida, yaitu internet dan media sosial sebagai media komunikasi pemasaran dan Word of Mouth (WOM) sebagai bauran promosi. Adapun frekuensi penggunaan media komunikasi tergolong sedang, sedangkan pada frekuensi penggunaan bauran promosi tergolong rendah. Sedangkan biaya pelaksanaan komunikasi pemasaran usaha kerajinan di Kota Bogor tergolong rendah.

Berdasarkan hasil penelitian terhadap UMKM kerajinan di Kota Bogor, sebagian besar usaha kerajinan memiliki kualitas daya saing sedang dalam hal tingkat produktivitas, tingkat profit, dan luas cakupan pasar.

Hasil uji korelasi antara variabel-variabel karakteristik UMKM (skala usaha dan tingkat pendidikan pelaku usaha) dengan variabel-variabel pelaksanaan komunikasi pemasaran (ragam media komunikasi, ragam bauran promosi, frekuensi penggunaan media komunikasi, frekuensi penggunaan bauran promosi, dan biaya pelaksanaan komunikasi pemasaran) menunjukkan nilai koefisien korelasi pada masing-masing variabel yang diuji yang lebih besar dari taraf nyata atau $\alpha$ sebesar 0.05. Sehingga, dapat disimpulkan bahwa antara variabel karakteristik UMKM kerajinan dengan variabel pelaksanaan komunikasi pemasaran tidak terdapat hubungan yang nyata dan tidak signifikan.

Hasil uji korelasi Rank Spearman antara pelaksanaan komunikasi pemasaran dengan tingkat kualitas daya saing menunjukkan bahwa nilai koefisien korelasi sebesar 0.443 dengan nilai signifikasi ialah sebesar 0.014 , dimana nilai tersebut lebih kecil dari taraf nyata atau $\alpha$ sebesar 0.05 . Nilai tersebut menunjukkan bahwa kedua variabel berhubungan cukup kuat dan signifikan.

\section{Saran}

Hasil penelitian menunjukkan bahwa media yang banyak digunakan untuk pemasaran adalah media sosial. Maka perlu dilakukan pelatihan tentang bagaimana manajemen pemasaran melalui media sosial baik dalam hal konten, visualisasi produk, dan intensitas melayani konsumen via media sosial. Selain itu perlu menggunakan media komunikasi yang lebih beragam seperti media massa, kelompok, dan personal dalam melakukan komunikasi pemasaran. Sedangkan dalam penggunaan bauran promosi, Pelaku usaha atau perajin harus meningkatkan pelayanan kepada konsumen. Hal ini karena berdasarkan hasil penelitian, bauran promosi WOM mendominasi dibandingkan ragam bauran promosi yang lain. Selain itu pelaku usaha kerajinan harus menggunakan bauran promosi yang lebih beragam seperti periklanan, promosi penjualan, humas, dan lain-lain. Pelaksanaan komunikasi pemasaran tidak terlepas dari pertimbangan biaya pemasaran yang diatur dengan sistem manajemen yang baik. Hal lainnya yang dapat dilakukan ialah menarik konsumen melalui produk kerajinan yang unik, berkualitas, dan bermanfaat, pengemasan produk, intensitas promosi yang tinggi, sistem reseller, dan lain sebagainya.

Pelaku UMKM kerajinan harus mengembangkan inovasi dan kreatifitas dalam menghasilkan produk, karena produk kerajinan merupakan barang komplementer, dimana hanya karena alasan tertentu konsumen akan membelinya. Mutu dan kuantitas produk tersebut dipengaruhi oleh kualitas dan kuantitas SDM, sehingga harus diperhatikan dalam hal rekruitmen dan pelatihan keterampilan pekerja. 
Pelaku usaha harus dapat melihat trend pasar melalui identifikasi segmentasi pasar. Selanjutnya, dalam hal pemilihan media dan bauran promosi harus disesuaikan dengan pasar sasaran, dimana kedua hal tersebut dapat menjangkau khalayak luas.

Pemerintah dalam hal ini Dekranasda dan beberapa dinas yang memiliki tugas pokok berkaitan dengan pengembangan UMKM, perlu melakukan perbaikan manajemen khususnya pada Dekranasda, sehingga para perajin mau menyimpan produk kerajinan di showroom Dekranasda. Kemudian, menekankan para pelaku UMKM untuk memiliki Tanda Daftar Industri (TDI), Surat Izin Usaha Perdagangan (SIUP), dan produk yang berlabel Standar Nasional Indonesia (SNI). Selain itu perlu meningkatkan frekuensi pelatihan, pameran, dan seminar bagi UMKM serta menarik minat perajin untuk mengadakan pertemuan rutin di showroom dalam rangka sharing ide dan membangun jaringan baik dengan sesama perajin maupun dengan lembaga lain.

\section{DAFTAR PUSTAKA}

[BI] Bank Indonesia. 2008. Undang- Undang Nomor 20 Tahun 2008 Tentang Usaha Mikro, Kecil, dan Menengah. [Internet]. [diunduh tanggal 27 Februari 2014]. Dapat diunduh dari: www.bi.go.id

Isnaini S. 2010. Implementasi komunikasi pemasaran terpadu sebagai penyampai pesan promosi usaha kecil menengah (UKM) di Indonesia. J Masyarakat Kebudayaan dan Politik [Internet]. [diunduh tanggal 19 Februari 2014]. 4: 324-332. Dapat diunduh dari: http://journal.unair.ac.id

Kotler P, Keller KL. 2009. Manajemen Pemasaran. Edisi Ke-13 (Alih bahasa dari Bahasa Inggris oleh Sabran B). Edisi 13. Jilid 2. Jakarta (ID): Erlangga. [Judul asli: Marketing Management, Thirteenth Edition. 436 hal.

Kusumastuti YI. 2009. Komunikasi Bisnis. Bogor (ID): IPB Press. 201 hal.

Mugniesyah SS. 2009. Media Komunikasi dan Komunikasi Massa. Dalam: Dasar-dasar Komunikasi. Bogor (ID): Sains KPM, IPB Press. 392 hal.

Sarwono J. 2009. Statistik itu Mudah: Panduan Lengkap untuk Belajar Komputasi Statistik Menggunakan SPSS 16. Yogyakarta (ID): ANDI OFFSET.
Sulistyastuti, Dyah R. 2004. Dinamika usaha kecil dan menengah (UKM): Analisis konsentrasi regional UKM di Indonesia 1999-2001. J.Ekonomi Pembangunan. [Internet]. [diunduh tanggal 9 Mei 2014] 9(2): 143-164. Dapat diunduh dari: http://journal.uii.ac.id

Tambunan TTH. 2009. UMKM di Indonesia. Bogor (ID): GHALIA INDONESIA. 282 hal.

Tjiptono F. 2008. Strategi Pemasaran. Edisi Ketiga. Yogyakarta (ID): ANDI OFFSET. 590 hal.

Widhi N. 2005. Kisah Sukses Pengusaha Mikro. Jakarta (ID): PT Pustaka Binaman Pressindo. 248 hal. 